Por Fernanda Maria Pereira

\title{
Pruno Torchia
}

Mestre em Direito Público (FUMEC), especialista em Prevenção e Repressão à Corrupção (Estácio de Sá) e em Combate ao Crime Organizado (Università degli Studi di Roma - TorVergata). Coordenador do MBA de Governança, Riscos, Regulação e Compliance, do MBA em Gestão Inovadora em Serviços de Saúde e do MBA em Segurança do Paciente e Gestão Estratégica em Saúde da Faculdade Unimed. 


\section{COMO O COMPLIANCE PODE SER UM DIFERENCIAL NA GESTÃO DAS ORGANIZAÇÕES}

O compliance está conexo ao controle de condutas corporativas relacionadas a interesses pessoais, que se baseiam em fraudes e na ausência de regulamentação precisa nas informações e demonstrações financeiras e contábeis. Por isso, cada vez mais, agir em conformidade com a lei deixou de ser apenas uma obrigação: tem se tornado um diferencial para a gestão e para a imagem de qualquer organização.

Nesta entrevista, o mestre em Direito Público Bruno Torchia fala sobre a origem do compliance, os desafios para sua implantação e qual a sua relação com a Lei Geral de Proteção de Dados Pessoais (LGPD), que passará a viger este ano no Brasil.

\section{Quando e por qual motivo surgiu o compliance?}

Precisar o surgimento do compliance é tarefa complexa. Há quem diga que ele surge em 1977, após a edição do Foreign Corrupt Pratices Act (FCPA), que é a "Lei Anticorrupção" norte americana. Outros dizem que sua origem está ligada ao caso Enrom, uma das maiores fraudes ocorridas nos EUA, em 2001, na qual a organização que chegou a valer cerca de 65 bilhões de dólares decretou falência em apenas 24 dias em razão de violações contábeis. No Brasil, o surgimento do compliance se dá com a edição da Lei n. 9.613/98, a Lei de Lavagem de Dinheiro, que impôs a determinadas pessoas obrigações de controle e fiscalização, sendo remodelado após a edição da Lei n. 12.846/2013, a Lei Anticorrupção.

\section{Quais são suas principais premissas?}

Segundo a Controladoria-Geral da União, o compliance se estrutura em cinco pilares, sendo eles comprometimento e apoio da alta direção; instância responsável, ou seja, ter uma área de compliance com independência e autonomia; análise de perfil e riscos; estruturação das regras e instrumentos; e estratégias de monitoramento contínuos. Destaca-se, porém, que referido rol pode ser ampliado, pois não se pode esquecer de incluir as due diligences, canais de denúncias, investigações internas e previsão de medidas disciplinares. 
3. O que levou o compliance a ganhar mais relevância no meio corporativo nos últimos anos?

O compliance tem sido visto pelo governo, sociedade e mercado como o mecanismo capaz de extirpar os atos ilícitos do meio negocial e disseminar a cultura de integridade nos negócios. Não apenas, as organizações têm paulatinamente exigido que seus fornecedores se alinhem às práticas de compliance, sob pena de não mais se relacionarem com eles. Conclui-se que estar em compliance é imperativo no que tange ao aspecto regulatório, concorrencial e negocial.

\section{A nova Lei Geral de Proteção de Dados Pessoais (LGPD), que passará a valer este ano no Brasil, tem interferência nisso? Se sim, qual?}

Atualmente, a LGPD pode ser vista como mais uma etapa na implantação do compliance, pois passa a exigir que as organizações adotem medidas de segurança, técnicas e administrativas aptas a proteger os dados pessoais de acessos não autorizados e de situações acidentais ou ilícitas de destruição, perda, alteração, comunicação ou qualquer forma de tratamento inadequado ou ilícito.

As organizações, portanto, precisam implantar mecanismos de Governança da Privacidade, o que impacta diretamente na condução de qualquer atividade empresarial. Sendo assim, o investimento em programas de compliance proporcionará conformidade à exigência regulatória, melhoria de processos internos e maior eficiência.

\section{Qual a relação dessas práticas com a saúde?}

No caso da LGPD, há pontos específicos para a área da saúde que devem ser observados com atenção. Entre eles, é expressa a vedação que as operadoras de planos privados de assistência à saúde não podem utilizar os dados sensíveis de saúde para a prática de seleção de riscos na contratação de qualquer modalidade, assim como na contratação e exclusão de beneficiários. Há que se analisar com cautela, também, se o tratamento de dados decorre de autorização legal ou demanda consentimento.

\section{Quais são as penalidades para as organizações que não se adequarem à LGPD?}


A organização que não se adequar, fizer mau uso dos dados ou se envolver em um incidente de segurança pode ser penalizada, com punições regulatórias que vão desde uma advertência até multa pecuniária que chega à monta de 50 milhões de reais (até $2 \%$ do faturamento), publicização da infração e do bloqueio e eliminação de dados da base da instituição, além de medidas judiciais promovidas pelos órgãos públicos competentes, tais como o Ministério Público, que poderá manejar Ação Civil Pública.

\section{Pensando sob o ponto de vista da gestão, por que adotar as práticas de compliance é um diferencial?}

O cumprimento de normas legais e regulamentares, quando se torna uma missão da organização, gera, acima de tudo, a confiança, ingrediente integral em qualquer prática comercial. Ademais, os gestores estão bastante propensos a sofrerem as consequências jurídicas de qualquer responsabilização, seja por responder com seu patrimônio ou por ser visto como alguém negligente neste processo.

\section{Quais os desafios para tornar o compliance uma realidade nas empresas, principalmente em relação à gestão de custos e de pessoas?}

O mais importante é a alta direção estar ciente da necessidade de implantar programa de compliance que, além de prevenir atos ilícitos de corrupção, esteja apto a proteger os dados pessoais dos titulares, garantindo recursos humanos, tecnológicos e financeiros.

É recomendável estabelecer um líder ou um grupo de líderes que ficarão a cargo da implementação dos processos de compliance e LGPD, os quais demandam conhecimentos multidisciplinares. Caso a organização não possua estes profissionais internos, pode trabalhar com consultoria externa especializada que dará esse suporte. A tarefa exige profissionais tanto da TI como do Direito, e a implantação dos mecanismos de compliance é um indicativo claro para os usuários e para os órgãos reguladores que a organização se preocupa com as normas e está envidando todos os esforços para alcançar esse objetivo.

Outra etapa muito importante são os treinamentos, que devem atingir toda a organização. $\mathrm{O}$ compliance e a LGPD são realidade no Brasil, e as organizações que não estiverem preparadas estarão, com toda certeza, sujeitas à perda de competividade negocial. 